CDE

March, 2003

\title{
Do Stock Markets Penalise Environment-Unfriendly Behaviour? Evidence from India
}

\author{
Shreekant Gupta \\ Delhi School of Economics \\ Email: shreekant29@yahoo.com \\ $\&$ \\ Bishwanath Goldar \\ Institute of Economic Growth \\ Email: b_goldar77@yahoo.com \\ Working Paper No. 116
}

\section{Centre for Development Economics}

Department of Economics, Delhi School of Economics 


\title{
Do Stock Markets Penalise Environment-Unfriendly Behaviour? Evidence from India
}

\author{
Shreekant Gupta \\ \& \\ Bishwanath Goldar
}

\begin{abstract}
A growing body of research points to the fact that capital markets react to environmental news and thus create incentives for pollution control in both developed and emerging market economies. In this paper we conduct an event study to examine the impact of environmental rating of large pulp and paper, auto and chlor alkali firms on their stock prices. We find that the market generally penalizes environmentally un-friendly behaviour in that announcement of weak environmental performance by firms leads to negative abnormal returns of up to 43 percent. A positive correlation is found between abnormal returns to a firm's stock and the level of its environmental performance. These findings should be viewed as further evidence of the important role that capital markets could play in environmental management, particularly in developing countries where environmental monitoring and enforcement are weak.
\end{abstract}

JEL Classification: Q25, G14, L73

Keywords: green rating, capital market, environmental management, event study

\section{Acknowledgements}

We thank the Centre for Development Economics (CDE), Delhi School of Economics for providing financial assistance for this study. We would also like to thank Supriya Singh for able research assistance in extracting and analysing the data, and the Centre for Science and Environment, New Delhi and CDE for providing the data for the study. 


\section{Introduction}

A growing body of research points to the fact that capital markets in developed market economies react to environmental news and thus create incentives for pollution controll. An important policy implication of this literature is that regulatory effort can be leveraged by the release of information regarding firms' environmental performance to markets. This aspect becomes particularly important in the context of developing countries where monitoring and enforcement capabilities are limited (Dasgupta et al., 2001).

Further, if the forgoing view about capital markets is valid they may be viewed as yet another pressure point in pollution abatement by firms-in addition to the pressure by regulatory agencies (either through command and control (CAC) or through market-based instruments or MBIs) and by communities ${ }^{2}$. Again, this is an important consideration for developing countries that face difficulties in implementing either CAC or MBIs based solutions.

Finally, in the context of increasing emphasis on voluntary programmes to improve environmental quality, if firms perceive this link (between their stock prices and their environmental track record) this creates another incentive for them to participate in voluntary environmental programmes (Alberini and Segerson, 2002).

In this paper we conduct an event study to examine the impact of environmental performance of large pulp and paper, automobile and chlor alkali firms in India on their stock prices. Our finding, namely, that the dissemination of knowledge about weak environmental performance of companies tends to lower the return to investors holding the stocks of such companies is important in light of the preceding statements. In sum, it lends credence to the view that even in emerging market economies such as India capital markets can: (i) leverage monitoring and enforcement activities, (ii) acts as an additional environmental pressure point on firms, and (iii) create incentives for participation in voluntary environmental programmes.

The following section describes how environmental performance is measured for the firms in our sample and compares this with a similar recent study for developing countries. In section III we describe the methodology and dataset.

1. See for instance Lanoie et al. (1998) and the references therein.

2. On the role of communities see Afsah et al. (1996), Blackman and Bannister (1998) and Pargal and Wheeler (1996). 
Section IV presents results. The final section discusses directions for further research and concludes.

\section{Measuring environmental performance of firms in India}

In this study we use the environmental rating by India's leading environmental NGO, the Delhi-based Centre for Science and Environment (CSE). Under its Green Rating Project (GRP), CSE evaluates the environmental performance for various industrial sectors. This project has been funded by the United Nations Development Programme (UNDP) through the central Ministry of Environment and Forests (MoEF). So far, CSE has rated firms/plants in pulp and paper, automobile manufacturing and chemicals (chlor alkali) sectors. There are plans to rate additional sectors and also to re-evaluate sectors that have already been rated such as pulp and paper (see www.cseindia.org/html/eyou/grp/grp index.htmfor details).

Thirty one large pulp and paper plants (capacity of 100 tons per day or more) representing 23 firms across 13 states were the first to be rated (Appendix 2-A). The exercise took about 18 months and the ratings were released on July 18, 1999. This was followed by a rating of 29 automobile manufacturers that was released on October 29, 2001 (Appendix 2-B). Finally, 25 chlor alkali firms comprising about 90 percent of the caustic-chlorine sector were evaluated and the ratings were released on September 2, 2002 (Appendix 2-C). As we note below in the description of our dataset, the release of these environmental ratings are high profile and prominent events that are widely reported in the media.

While credit rating agencies exist in India, the GRP is the first attempt at environmental rating of firms in the country ${ }^{3}$. In the absence of a comprehensive reporting system such as the Toxics Release Inventory (TRI) in the United States, the GRP relies heavily on voluntary disclosure of information by firms. This information is acquired by CSE through structured surveys and fieldwork and is reviewed and vetted by technical experts ${ }^{4}$. A life cycle analysis (LCA) beginning from raw material procurement to product recycling, is used to study the environmental impact of a firm. To elaborate, environmental impacts at the following

3. "The uniqueness of GRP is that this is the first time anywhere in the developing world that the environmental performance rating of industrial firms is being undertaken by an NGO and that information of the environmental performance of companies is being made available to the public." (CSE website, accessed 2.3.2003).

4. For further details see http://www.cseindia.org/html/eyou/grp/grp rating method.htm 
stages of the life cycle are analysed: (a) during sourcing of raw materials, (b) during production, that is, processing of raw material into final products, (c) during product use, and (d) during disposal of the products. This approach is operationalised through the following six broad criteria and their components:

1. Sourcing and processing raw materials

2. Plant level environmental performance

(i) input management

(ii) process management

(iii) waste management

3. Product-use performance

4. Product-disposal performance

5. Corporate environmental policy and management systems

(i) corporate policy related to environment

(ii) procurement policy and supply chain management

(iii) status of corporate environmental management and environment management systems (EMS)

(iv) research and development

(v) health and safety

(vi) transparency

6. Community and regulatory perception and compliance status

(i) compliance with pollution control board (PCB) regulations and perception of PCB officials

(ii) perceptions of local community

(iii) perceptions of local NGOs and media

(iv) perception of CSE's green inspector

It should be noted, however, that the weights assigned to various criteria vary substantially across the three sectors based on their inherent characterises. For instance, in the case of pulp and paper firms, maximum weight was given to procurement of raw material and production phases, whereas for automobile firms highest weight was assigned to the product use phase. This reflects the implicit assumption that environmental impacts of different sectors occur at different stages 
of the life cycle. As we see later, this may have implications for the findings of our study.

Table 1 summarises the weights used by the CSE for the computation of environmental scores based on which green ratings are given. Some more details regarding the weights assigned to various criteria for rating pulp and paper and automobile firms are shown in Appendix 1-A and 1-B, respectively. While the rating categories across the two sectors are not identical, nevertheless there are some striking differences in the weights assigned. First, while plant-level performance (particularly process management) is assigned considerable weight for pulp and paper (50) the corresponding weight for automobiles is 11.5. Secondly, product use and disposal have been assigned zero weight for pulp and paper but 61 for automobiles.

Table 1: Weights assigned for computation of green rating by the CSE

\begin{tabular}{|l|r|r|r|}
\hline Segment & \multicolumn{3}{|c|}{ Weights } \\
\hline & 20.0 & Pulp and Paper sector & Chlor-alkali sector \\
\hline $\begin{array}{l}\text { Corporate environmental } \\
\text { policy and management }\end{array}$ & Automobile sector & 35.0 & 15.0 \\
\hline Life cycle analysis & 77.0 & 50.0 & 75.0 \\
& & & 6.0 \\
- sourcing phase & 7.5 & 42.0 & 52.5 \\
- production phase & 8.5 & 0.0 & 16.5 \\
- product use and & 61.0 & 15.0 & 10.0 \\
\hline - disposal phase & & & \\
(primary survey & 3.0 & & \\
community, NGOs, etc.) & & & \\
\hline
\end{tabular}

Source: Centre for Science and Environment (CSE), New Delhi.

It is also important to note that the Green Rating Project benchmarks environmental performance against "theoretical best practice" for the various components/criteria. In other words, companies/plants/products are not rated against current environmental norms, standards or regulations but against an ideal best practice. In fact, full compliance with current environmental regulations merely fetches a score of 2 on a 10 point scale. 
Specifically, the green rating uses the following scores on a 10 point scale for each component/criterion: Indian average/standard/legal requirement 2, global best practice 8 , theoretical best practice 10 . In other words, wherever a domestic sourcespecific discharge standard exists it is taken as the lowest benchmark (2 points). In case there is no such standard as in the case of $\mathrm{SO}_{2}$ emissions, the average discharge for all plants in the sample is taken as the lowest benchmark and below average performance is given zero, the best performance gets 8 and there is a liner scale between 2 and $8^{5}$. The points given to global best practice and theoretical best practice reflect an incentive for better environmental performance. It is, therefore, important to bear in mind that the rating emphasises overcompliance with current standards or practices. This point is particularly relevant when we interpret the results of our study. In other words, what is the nature of the 'event' that capital markets are reacting to?

The final rating is a "green leaves" award ranging from no award to five leaves ${ }^{6}$. While such ratings are subject to the usual index number problem, we believe they are a consistent and careful evaluation of firm-level environmental performance. Similar exercises entailing public disclosure of firms' environmental performance have been carried out in a few other developing countries such as Indonesia's PROPER programme, in the Philippines under the Ecowatch programme, and in China under the Green Watch programme $\mathrm{C}^{7}$. There are, however, very few studies for developing market economies that examine the impact of such environmental performance on capital markets. Notable among these is a recent exercise by Dasgupta, Laplante and Mamingi (2001) that shows capital markets in Argentina, Chile, Mexico and Philippines react to both positive and negative environmental news. In that study for each of the four countries, environmental news on firms traded in local capital markets was collected over a four year period (1990-1994) from one leading daily newspaper. This news (or 'event') was classified as positive (e.g., rewards, investment in pollution control) and negative (e.g., spills,

5. For paper and pulp the linear scale ranged from 2 through 10 but was later capped at 8 for automobiles and chlor alkali.

6. The cutoff scores for each level are 5 leaves (75-100), 4 leaves (50-74.9), 3 leaves (35-49.9), 2 leaves (25-34.9), 1 leaf (15-24.9), and no award for $<15$.

7. For details on the disclosure programmes in Indonesia and the Philippines see World Bank (1999) and for that in China see Wang et al. (2002). The impact of Indonesia's PROPER on environmental quality is examined by Afsah and Vincent (1997). 
complaints and warnings). Total 'events' during this period ranged from 18 (Philippines) to 53 (Chile) covering 10 firms each in Philippines and Mexico, 11 in Argentina and 17 in Chile. On the whole, with respect to positive news there was a statistically significant increase in market values for 20 events out of 39 . For negative news the corresponding figure was 33 events out of 85 .

In contrast, our study uses a standardised one-shot event, namely, the announcement of green ratings and leaf awards on July 18, 1999 for pulp and paper firms, October 29, 2001 for automobile firms and September 2, 2002 for firms in the chlor alkali sector. This has the advantage that it rules out possible selection bias of only 'newsworthy' (very good/bad) events being reported. And it is the same event across all firms. Further, in our study we only consider one event per firm, whereas Dasgupta et al. (2001) consider multiple bad (and good) 'events' for various firms. For instance, in Philippines for San Miguel (a brewing company) positive news was reported three times within a span of ten months (Table V, op. cit.). Only one of these three 'events' resulted in a statistically significant increase in market value. In such instances of repeated positive (or negative) news for the same firm it is possible that investors may be discounting such news. Finally, unlike classification of events simply as positive or negative, the environmental rating we use provides a complete ordering of firms (see Appendix Tables 2-A, 2-B and 2-C). In sum, we believe that we are able to bring to data a more objective and consistent measure of firm-level environmental performance for a developing country than has been done so far.

In this context, it may be mentioned that India's stock market capitalisation is about US\$300 billion (April 2000) - the highest among emerging market economies. Further, the industrial sectors rated by CSE so far are experiencing rapid growth or occupy an important position on the Indian industrial scene. Paper and pulp and caustic soda are also among the 17 "highly polluting" industrial sectors as identified

8. The chlor alkali industry forms the backbone of the chemicals sector in the country. In recent years all three segments of this industry (caustic soda, soda ash and chlorine) have experienced generally positive though sluggish growth in output, except chlorine that has recorded double-digit growth. Caustic soda, a basic inorganic chemical, is primarily used for the manufacture of paper, detergents, aluminium, viscose and other products. Chlorine is a by-product, and for every ton of caustic soda manufactured, 0.8 tons of chlorine is produced. In the automobile sector, 2 and 3 wheelers make up the largest segment in terms of numbers and have registered growth rates in double digits. The 4 wheeler segment shows slower though steady growth, as does the pulp and paper sector. 
by the Central Pollution Control Board (CPCB) for implementation of pollution control programs (http://cpcb.nic.in/17cat/17cat.html). In other words, these two sectors are among those that appear to be the focus of environmental regulatory attention and are regularly highlighted in the annual reports of CPCB and on its website. Most state pollution control boards (SPCBs) also take their cue from CPCB in focusing on these sectors. The same is the case with automobile firms where the environmental performance of their products, namely, motor vehicles has been the subject of intense judicial and regulatory activity in India in recent years.

\section{Framework, methodology and data}

In an efficient capital market, stock prices on any day fully reflect available information about the present value of the stream of profits that a firm is expected to earn in the future (Fama, 1991). The provision of new information about the environmental performance of a firm may cause abnormal changes in its stock price, if this information diverges from the investors' expectations about such performance and is perceived by them to affect the profitability of the firm. This is the theoretical framework that underlies the event study methodology, applied by Khanna et al. (1998), Arora (2001), Dasgupta et al. (2001) as well as other researchers to examine the reaction of capital market to environmental news.

It is generally believed that in developing countries capital markets are not as efficient as in developed countries and are therefore not expected to respond to new environmental information about firms in the same way. As discussed earlier, however, Dasgupta et al. (2001) show that capital markets in developing countries do respond to environmental news. Accordingly, we conduct an event study to assess the impact of the announcement of environmental rating of large pulp and paper, auto and chlor alkali plants in India on the stock prices of the firms to which they belong. Our aim is to investigate whether the capital market in India responded significantly to the announcement of the ratings of plants belonging to these industries and the nature of this response.

\section{Event study methodology}

There are alternative models for carrying out an event study (MacKinlay, 1997). One of them is the market model. Khanna et al. (1998), Arora (2001) and several other 
event studies have used the market model (see MacKinlay (op. cit.) on the advantages of the market model). In this study we use the market model as well.

The market model assumes a linear relationship between the return of any security and the return of the market portfolio:

$$
R_{i t}=\alpha_{i}+\beta_{i} R_{m t}+e_{i t}
$$

with $E\left(e_{i t}\right)=0$ and $\operatorname{Var}\left(e_{i t}\right)=\sigma_{e_{i}}^{2}$

where $t$ is the time index and $i=1, \ldots, \mathrm{N}$ represents securities. $R_{i t}$ and $R_{m t}$ are the return on security $i$ and the market portfolio, respectively, during period $t$, and $e_{i t}$ is the random error term associated with security $i$.

For estimation of the model, first the event window is defined. This could be just one day after the event, or more than one day after the event. Sometimes, days prior the event are also included in the event window. Equation (1) is typically estimated over a period of 120 to 210 days prior to the event window. The commonly used estimation method for the market model is Ordinary Least Squares (OLS). Given the estimates of $\alpha$ and $\beta$ for each firm, the abnormal return for firm $i$ in period $t$ (say, day $\mathrm{t}$ ) in the event window is defined as:

$$
A R_{i t}=R_{i t}-\hat{\alpha}_{i}-\hat{\beta}_{i} R_{m t}
$$

The abnormal return is the disturbance term of the market model calculated on an out of sample basis. Under the null hypothesis, conditional on the event window market returns, the abnormal returns will be jointly normally distributed with a zero conditional mean and conditional variance $\sigma^{2}\left(R_{i t}\right)$ (MacKinlay, 1997). If the period used for the estimation of the model is large, $\sigma^{2}\left(R_{i t}\right) \rightarrow \sigma_{e_{i}}{ }^{2}$.

To test for the persistence of the impact of the event during a period $T_{1}$ to $T_{2}$ (in the event window) the abnormal returns of a given security can be added to

9. Dasgupta et al. (2001) have applied the constant mean return model as they did not have data on market returns. Where they could find data on market returns, they also obtained results using the market model. 
obtain cumulative abnormal returns. Cumulative abnormal return (CAR) for security $i$ for the period $T_{1}$ to $T_{2}$ is given by:

$$
\operatorname{CAR}_{i}\left(T_{1}, T_{2}\right)=\sum_{t=T_{1}}^{T_{2}} A R_{i t}
$$

The variance is given by:

$$
\sigma_{i}^{2}\left(T_{1}, T_{2}\right)=\left(T_{2}-T_{1}+1\right) \sigma_{e_{i}}^{2}
$$

Given the CAR and its variance, the null hypothesis of zero cumulative returns can be tested by applying a z-test, because $C A R_{i}\left(T_{1}, T_{2}\right) \sim N\left(0, \sigma_{i}^{2}\left(T_{1}, T_{2}\right)\right)$.

These cumulative returns can also be aggregated across the $\mathrm{N}$ scripts and average cumulative abnormal returns (CAAR) can be obtained as:

$$
\operatorname{CAAR}\left(T_{1}, T_{2}\right)=\frac{1}{N} \sum_{i=1}^{N} \operatorname{CAR}\left(T_{i}, T_{2}\right)
$$

and, the variance of CAAR is:

$$
\operatorname{var}\left(\operatorname{CAAR}\left(T_{1}, T_{2}\right)\right)=\frac{1}{N^{2}} \sum_{i=1}^{N} \sigma_{i}^{2}\left(T_{1}, T_{2}\right)
$$

Under the null hypothesis that the abnormal returns are zero,

$$
Z=\frac{\operatorname{CAAR}\left(T_{1}, T_{2}\right)}{\left(\operatorname{var}\left(\operatorname{CAAR}\left(T_{1}, T_{2}\right)\right)\right)^{1 / 2}} \sim \mathrm{N}(0,1)
$$

Thus, a z-test can be carried out to test for the statistical significance of average cumulative abnormal return across the $\mathrm{N}$ scripts. It should be pointed out here that the distributional result in (7) above is asymptotic with respect to the number of scripts and the period of estimation (MacKinlay, 1997). 
We use data on stock prices for 17 pulp and paper firms, 15 auto firms and 18 chlor alkali firms for this study. These are firms whose plants were included in the Green Rating Project of CSE. As mentioned earlier, environmental ratings for pulp and paper industry were announced by CSE on July $18^{\text {th }} 1999$, those for automobile firms were announced on October $29^{\text {th }} 2001$, and for chlor alkali firms the ratings were declared recently on September $2^{\text {nd }} 2002$. The announcements of environmental ratings are high profile events with prominent persons such as the former Indian Finance Minister releasing the scores and distributing the 'leaf' awards. These events are accompanied by extensive media coverage.

To carry out the analysis, closing stock prices (adjusted for splits, bonuses, etc.) for the selected companies for 120 trading days prior to the announce of the rating and 30 trading days after the announcement have been taken from the corporate database PROWESS of Centre for Monitoring the Indian Economy $(\mathrm{CMIE})^{10}$. Since the market model is used, data on market returns are also needed. To this end, we use the popular Bombay Stock Exchange (BSE) "Sensex"

The event window has been defined as 15 trading days following the announcement of the green rating of plants. Days prior to the event have not been included in the event window, unlike Dasgupta et al. (2001), since there are no compelling reasons to believe that the market could have anticipated the ratings to be given by CSE under its Green Rating Project.

The market model has been estimated with data for 120 trading days prior to the event. In two paper firms, the estimated $\beta$ turned out to be negative when data for 120 trading days were used. For these two companies, a shorter period within

10. This database contains financial data on over 8,000 Indian firms from 1988-89 and is regularly updated. These are firms that are registered under the Companies Act and are typically large and medium firms and account for more than seventy per cent of the economic activity in the organised industrial sector of India. The data is primarily gathered from profit and loss statements and balance sheets of companies as well as other secondary sources. See http://www.cmie.com/products/prowess/index.htm for details.

11. Of 22 stock exchanges in India, the Bombay Stock Exchange is the largest, with over 7,500 stocks listed and accounts for over two thirds of total trading volume in the country. Established in 1875, the exchange is also the oldest in Asia. Approximately 70,000 deals are executed on a daily basis, giving it one of the highest per hour rates of trading in the world. There are about 3,500 companies in the country that are listed and have a significant trading volume. The market capitalization of BSE is 5 trillion rupees (Rs. $49=$ US $\$ 1$ ). The BSE Sensex is a widely used market index. It is a value-weighted index comprising 30 companies (base April $1979=100$ ). The set of companies in the index is essentially fixed and account for approximately one-fifth of the market capitalization of BSE. 
the 120 trading days has been used. The estimation period for these two companies was chosen by repeated trials, till the estimate of $\beta$ became positive and the $t$-ratio for the regression coefficient was found to be more than one.

As stated earlier, CSE examined 28 units in the pulp and paper sector, 29 in automobiles and 25 in chlor alkali, with the rating ranging from five leaves (best) to one leaf, or even no leaf for the worst performance/non cooperation. In no case, was a four or five-leaf rating awarded-as noted earlier, firms/plants/products in the sample were not rated against current environmental norms, standards or regulations but against ideal best practice benchmarks. In fact, as already stated full compliance with current environmental regulations merely fetches a score of 2 on a 10 point scale. Thus, it seems unlikely that in the near future at least any firm/unit would get a 4 or 5 leaves award.

The companies chosen for the study are those who own one or more of the plants included in the rating exercise. For some of the plants, share prices of companies owning them were not available. These plants have therefore been excluded from the analysis.

Table 2 shows the distribution of the selected companies according to the ratings of the plants owned by them. Generally, there is a one-to-one correspondence between the plants rated and the companies selected for the study. But there are cases where a company had more than one plant rated. For instance, one pulp and paper company (Ballarpur Industries Ltd. - BILT) had three plants rated 'two leaves' and two plants rated 'one leaf'. Since this company had the majority of its plants in the 'two leaves' category, the overall rating of the company has been taken as 'two leaves'. Similarly, one company belonging the chlor alkali sample had one plant in the 'three leaves' category and two plants rated as 'two leaves'. Thus, the overall rating of the company has been taken as two leaves. 
Table 2: Distribution of Companies according to the rating of their unit/plants

\begin{tabular}{|l|c|c|c|}
\hline Rating & \multicolumn{3}{|c|}{ Industries } \\
\hline One leaf & Pulp and paper & Automobiles & Chlor alkali \\
\hline Two leaves & 8 & 4 & 4 \\
\hline Three leaves & 7 & 8 & 8 \\
\hline No rating given & 2 & 2 & 5 \\
\hline Total companies & - & $1^{*}$ & $1^{*}$ \\
\hline
\end{tabular}

* For plants belonging to these companies, no rating is given. However, their rank and scores indicate that they are at the bottom in terms of environmental performance.

\section{Results}

Table 3 shows the average abnormal return for the day following the announcement (event) and average cumulative abnormal returns (CAAR) for five, ten and fifteen days after the event, for the three industrial sectors. The average abnormal return for the 17 pulp and paper firms taken together on the first day after the announcement of green ratings is negative but not statistically significant. That is not the case, however, for event windows longer than a day. Thus, cumulative abnormal returns averaged across the 17 firms (CAAR) are negative and statistically significant for the five trading days period (0-5), the ten trading days period (0-10) and the fifteen trading days period (0-15). For the 15-days period following the announcement, the cumulative abnormal return is -0.27 on average, which is statistically significant at the two per cent level. This may be interpreted as showing an average loss of about 27 percent in stock value (over and above the changes in the market portfolio) caused by the announcement of green ratings.

It seems the announcement of green rating gave the impression to investors and the public that the environmental performance of pulp and paper mills in India was not up to the mark. Though some plants were rated better than others even their performance was much below global standards (and of course, theoretical best practice). No pulp and paper mill was given a rating of five or four leaves, and most were given a rating of 'one leaf' or 'two leaves'. The market seems to have taken this news as an adverse indication of the environmental performance of firms. 
Table 3: Average Cumulative Abnormal Returns (CAAR): Pulp and Paper, Automobile and Chlor Alkali Firms in India

Number of days
$\begin{array}{llll} \\ 0-1 & 0-5 & 0-10 & 0-15\end{array}$

Pulp and Paper firms

Average cumulative $-0.0229 \quad-0.1050 \quad-0.1912 \quad-0.2707$

abnormal return

$\begin{array}{lllll}\text { z-ratio } & -0.8168 & -1.6684 & -2.1489 & -2.4835\end{array}$

Automobile firms

$\begin{array}{lllll}\text { Average } & \text { cumulative } 0.0115 & 0.0529 & 0.0869 & 0.1305\end{array}$

abnormal return

$\begin{array}{lllll}\text { z-ratio } & 0.9013 & 1.8533 & 2.1508 & 2.6371\end{array}$

Chlor alkali firms

Average cumulative $-0.0077 \quad-0.0078 \quad-0.0433 \quad-0.0865$

abnormal return

$\begin{array}{lllll}\text { z-ratio } & -0.5777 & -0.2606 & -1.0209 & -1.6651\end{array}$

Pulp and Paper and

Chlor alkali firms

$\begin{array}{lllll}\text { Average cumulative }-0.0152 & -0.0550 & -0.1152 & -0.1760\end{array}$

abnormal return

z-ratio

$-0.9895$

$-1.6069 \quad-2.3784$

$-2.9674$

Somewhat similar results are obtained for the chlor alkali firms. The average abnormal return for day 0-1 and average cumulative abnormal return for days 0-5, 010 and $0-15$ are negative for chlor alkali firms, as in the case of pulp and paper. These, however, are not statistically significant, except the CAAR for the fifteen trading day period (statistically significant at 10 per cent level). Also, the negative abnormal return in chlor alkali firms is smaller than that for pulp and paper firms. This is perhaps expected since the proportion of companies awarded two or three leafs is relatively greater among chlor alkali firms compared to pulp and paper (Table 2).

Turning now to automobile firms, the results obtained are sharply at variance with those obtained for pulp and paper and chlor alkali firms. Here the average abnormal return for day $0-1$ and average cumulative abnormal return for trading days 0-5, 0-10 and 0-15 are positive. Also, the cumulative abnormal returns for days 0-5, 0-10 and 0-15 are statistically significant. 
The finding of positive abnormal return for auto firms could be due to some peculiarities of the industry and/or in the manner of rating. With regard to the latter, as noted earlier, the emphasis in the rating for this sector is on the product per se and not on the production process. Hence, the market may be discounting the mediocre ratings performance by firms in this sector as not being a true reflection of their environmental performance ${ }^{12}$. It is also possible given CSE's long running campaign against automobile companies and vehicular pollution, the market expected the worst from the green rating and was in fact pleasantly surprised when the ratings were not so harsh. In other words, better than expected performance could be viewed as positive performance news (with positive abnormal returns).

It should also be pointed out that the announcement of the green rating for this sector came at a time when the stock market was recovering rapidly from a large fall in stock prices it had experienced for nine-months or so. Between January and September 2001, the BSE Sensex fell from about 4500 to 2500 (Figure 1). Since October 2001, the stock market made a smart recovery and by December of that year, the index had recovered to about 3500. Since the announcement of green rating of auto firms was done at the end of October, there was a strong bullish phase in stock prices during the event period. This may have made it difficult for the simple statistical method applied to separate the effect of announcement of green rating by CSE from the effect of other forces working on stock prices of auto companies. This issue has been noted in the event study literature. For instance, Henderson (1990) observes, "If the type of event under study has a greater probability of occurring in a bull market than a bear market, it creates a problem. If expected residuals are based on an estimation interval where the market was not doing well, the conditional expectation of $R_{\mathrm{jt}}$ is misspecified, and that misspecification is introduced into the excess return calculation" (p. 294). Similarly, McWilliams and Siegel (1997) note that abnormal returns associated with an event can only be truly identified if, inter alia, (1) markets are efficient, (2) the event was unanticipated, and most critically (3) there were no confounding effects during the event window.

12. This observation goes to the heart of the question-even if we observe the impact of poor environmental performance on stock prices what is the reason for this causality to hold? Does it reflect possible future liability or simply increased pressure from civil society? As of now there is no theory for this causality. 


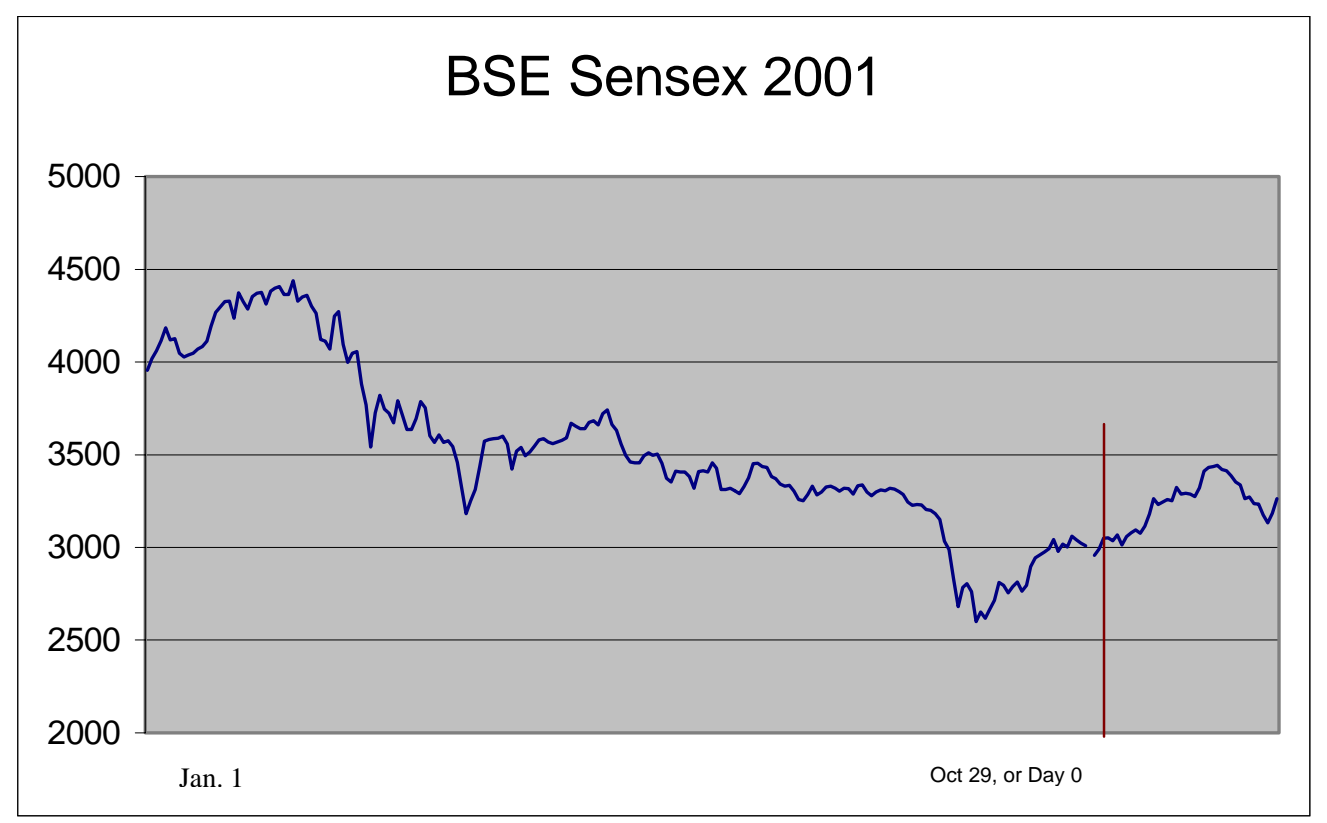

Figure 1

It is also interesting to note that though the average of abnormal returns for auto firms as a whole is positive, for some important companies, the abnormal returns for day $0-1$ and $0-5$ turn out to be negative, for example Hindustan Motors and Tata Engineering and Locomotives.

Since the results for automobile firms may have been affected by the bullish phase of the stock market at the time of announcement of the green rating and/or by some other factors, the rest of our analysis is based only on estimates for pulp and paper and chlor alkali firms. Thus, the bottom half of Tables 3 and 4 shows average abnormal returns combining only these two sectors, and distinguishing between oneleaf firms and those with more than one-leaf. The average abnormal return for day $0-1$ and average cumulative abnormal return for days $0-5,0-10$ and $0-15$ are all negative. Moreover, the averages for days $0-10$ and $0-15$ are statistically significant. 
Table 4: Average Cumulative Abnormal Returns: Pulp and Paper, and Chlor Alkali Firms

\begin{tabular}{|c|c|c|c|c|}
\hline & \multicolumn{4}{|c|}{ Number of days } \\
\hline & $0-1$ & $0-5$ & $0-10$ & $0-15$ \\
\hline \multicolumn{5}{|l|}{ Pulp and Paper } \\
\hline $\begin{array}{l}\text { Firms with one leaf } \\
\text { rating }\end{array}$ & -0.0556 & -0.1398 & -0.3049 & -0.4281 \\
\hline $\begin{array}{l}\text { Firms with two-leaves } \\
\text { rating or better }\end{array}$ & 0.0060 & -0.0740 & -0.0901 & -0.1307 \\
\hline \multicolumn{5}{|l|}{ Chlor alkali } \\
\hline $\begin{array}{l}\text { Firms with one leaf } \\
\text { rating }\end{array}$ & -0.0079 & -0.0384 & -0.1056 & -0.1788 \\
\hline $\begin{array}{l}\text { Firms with two-leaves } \\
\text { rating or better }\end{array}$ & -0.0074 & 0.0010 & -0.0225 & -0.0568 \\
\hline \multicolumn{5}{|l|}{$\begin{array}{l}\text { Pulp and Paper and } \\
\text { Chlor alkali } \\
\text { Firms with one leaf } \\
\text { rating ( } n=12)\end{array}$} \\
\hline $\begin{array}{l}\text { Average cumulative } \\
\text { abnormal return }\end{array}$ & -0.0397 & -0.1060 & -0.2385 & -0.3451 \\
\hline z-ratio & -1.0115 & -1.2087 & -1.9223 & -2.2710 \\
\hline \multicolumn{5}{|l|}{$\begin{array}{l}\text { Firms with two- } \\
\text { leaves rating or } \\
\text { better }(n=22)\end{array}$} \\
\hline $\begin{array}{l}\text { Average cumulative } \\
\text { abnormal return }\end{array}$ & -0.0019 & -0.0297 & -0.0502 & -0.0871 \\
\hline z-ratio & -0.1659 & -1.1582 & -1.3838 & -1.9600 \\
\hline
\end{tabular}

Comparing firms that were rated 'one leaf' with those that received two or three leaves, it is found that the average cumulative abnormal return for the 'one-leaf' companies is much more negative than that for the 'two leaf' and 'three leaf' groups. For the $0-15$ days period, for example, the average cumulative abnormal return for pulp for paper firms was $\quad-0.43$ for the 'one leaf' firms as against -0.13 for those that received more than one leaf. Similarly, in the case of chlor alkali firms, the average cumulative abnormal return for the 0-15 days period was -0.18 for companies awarded one leaf as against -0.06 for companies awarded two or three leaves. Combining the pulp and paper firms with the chlor alkali firms, the average 
cumulative abnormal return for the $0-15$ days period was -0.35 for companies awarded one leaf, statistically significant at five percent level. The corresponding figure for companies awarded two or three leaves was -0.09 , also statistically significant at five percent level.

The main point that emerges from Tables 3 and 4 is that the capital market seems to have penalised pulp and paper firms and chlor alkali firms for poor environmental performance, especially those whose performance was relatively worse. This is corroborated by Figure 2 that shows (for pulp and paper and chlor alkali firms combined) average cumulative abnormal return for different lengths of time up to 15 days following the announcement of green ratings.

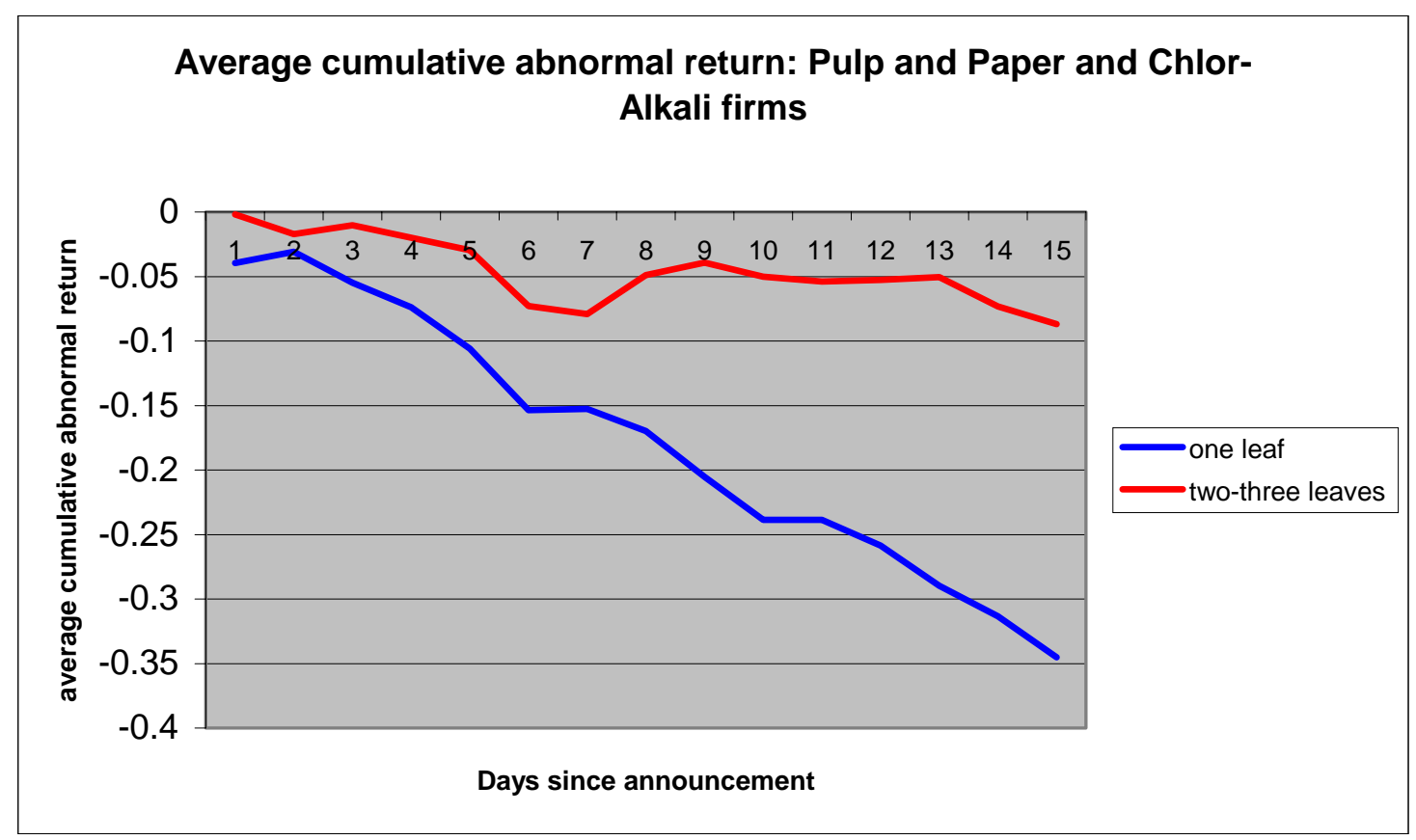

Figure 2

It is interesting to note that while the average cumulative abnormal return for the 'two-three-leaves' category stabilised after seven days, that for the 'one-leaf' category continued to fall.

Figure 3 presents a comparison of average cumulative abnormal return across three groups of firms on the basis of the score/ranking given by CSE--firms have been classified into three groups: the top one-third, the next one-third and the bottom one-third in terms of environmental performance. Cumulative returns for days $0-1,0-5,0-10$ and $0-15$ are shown in the graph. It is evident from the graph 
that the average cumulative abnormal return is negative for all three groups (except for the top ranking group for day 0-1). Further, the return is the worst for firms that received the lowest score/ranking.

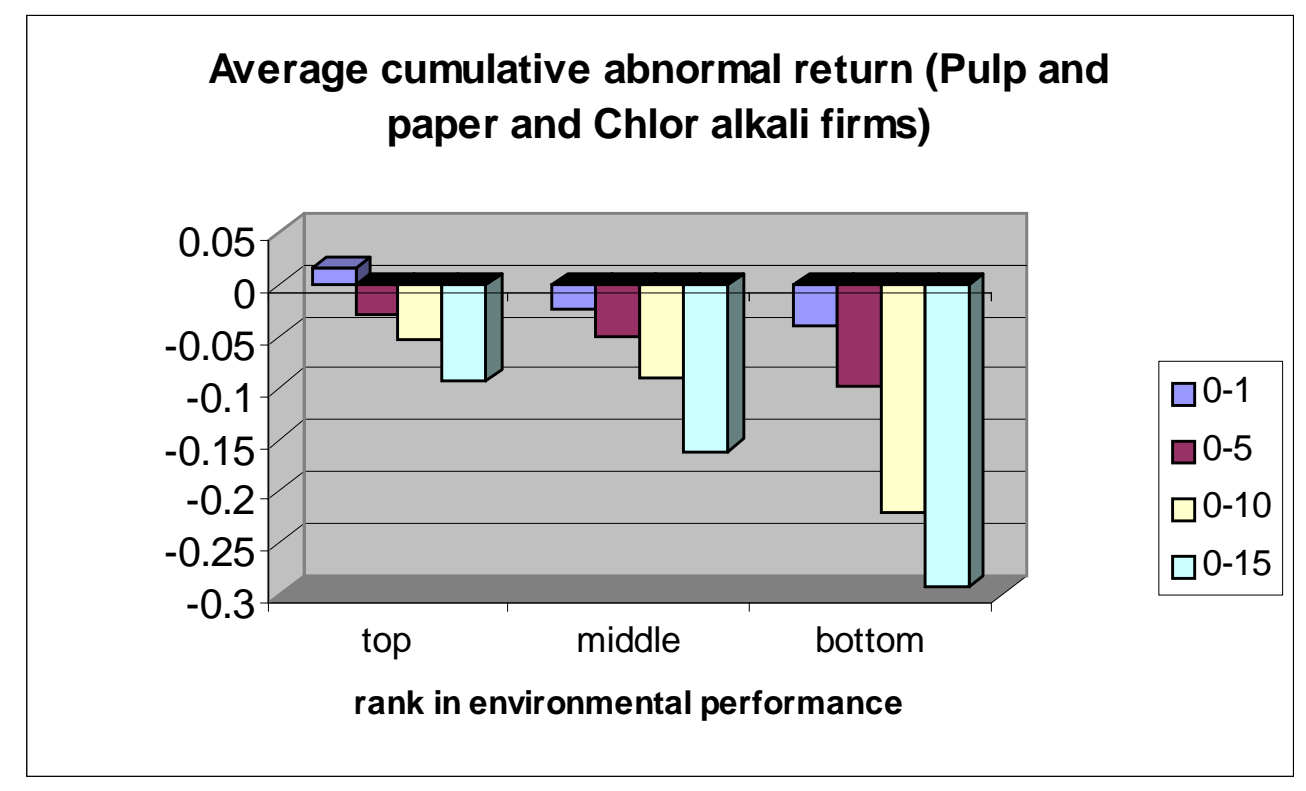

Figure 3

It should be pointed out here that in the sample of pulp and paper and chlor alkali firms combined (and also independently for the two groups) there is a significant positive correlation between the estimated abnormal return and the environmental score. The correlation coefficient between estimated abnormal return on the first day after the announcement and the weighted score is 0.54 (see Figure 4 for the plot). This is statistically significant at the one per cent level. The correlation coefficients for abnormal returns for days $0-5,0-10$ and $0-15$ are $0.35,0.43$ and 0.36 , respectively. All of these are statistically significant at five per cent or higher level. The finding of a significant positive correlation between environmental score and abnormal return as one would expect provides basis for confidence in the estimates of abnormal returns we have obtained. 


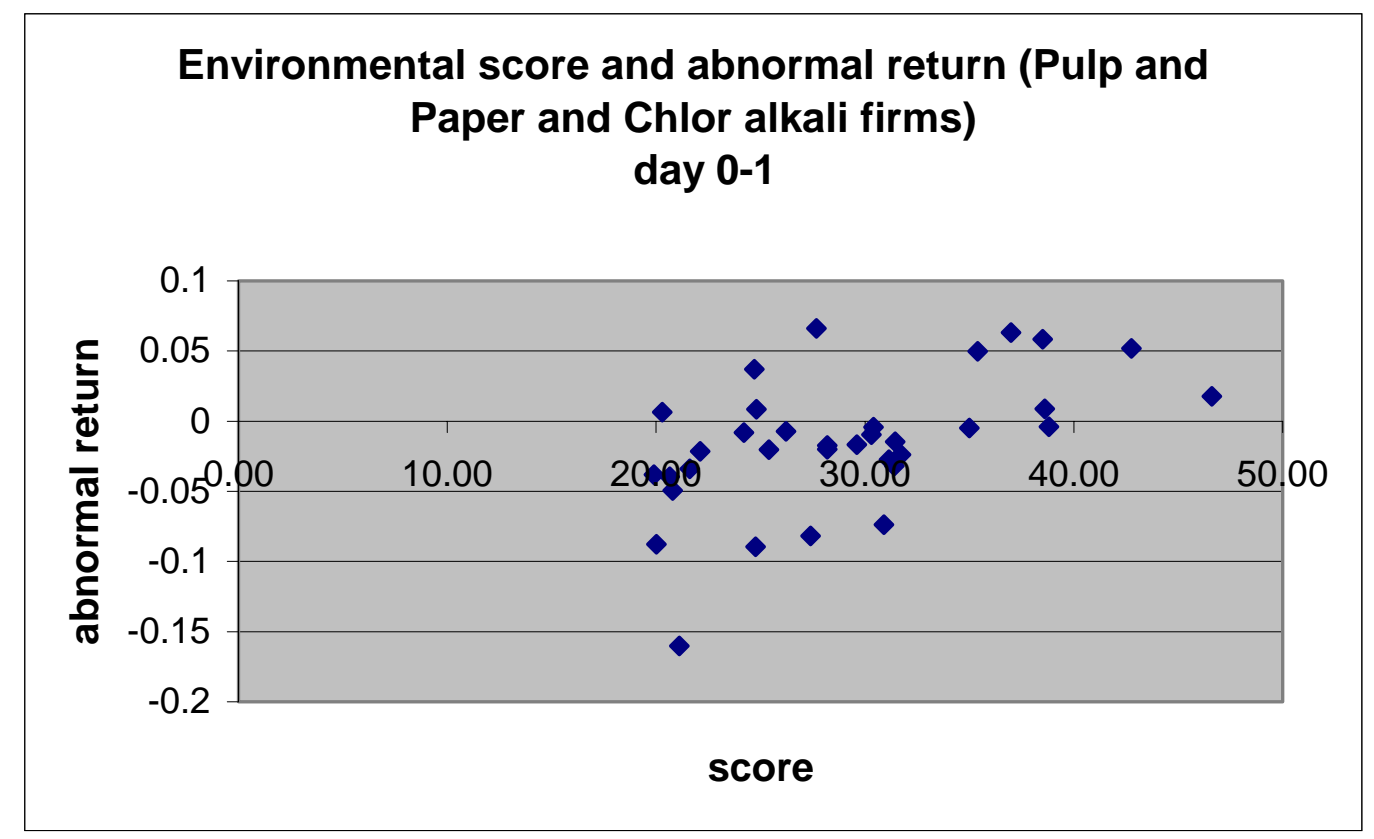

Figure 4

\section{Conclusions}

To our knowledge, this is the first attempt to examine the impact of public disclosure of environmental performance on the financial performance of firms for a developing economy. In future work it would be useful to examine if these findings are robust across sectors and over time. With respect to methodology, alternatives to the market model such as CAPM and the multifactor model (Tawil 1999) could be employed, again to test the robustness of the results. More important, however, in a developing country context where market adjustment is slow is the application of diffusion theory to test how markets adjust to 'events' (Boardman et al. 1997). These are issues for further research.

Our findings further strengthen the emerging view that capital markets bolster regulatory efforts in both developed and developing market economies. Specifically, a perception of weak environmental performance by dirty industries is penalized by negative abnormal returns. This result is not driven by disparate 'events' as in an earlier study but by a comprehensive and consistent green rating. Thus, an important policy implication of the research would be institutionalising such public disclosure programmes as a tool for environmental management in developing countries. 


\section{References}

Afsah, S., Laplante, B. and D. Wheeler (1996), "Controlling Industrial Pollution: A New Paradigm", Policy Research Working Paper 1672, Development Research Group, World Bank.

Afsah, S. and J. Vincent (1997), "Putting Pressure on Polluters: Indonesia's PROPER Program, A Case Study for the HIID 1997 Asia Environmental Economics Policy Seminar", Harvard Institute for International Development, March.

Alberini, A. and K. Segerson (2002), "Assessing Voluntary Programs to Improve Environmental Quality", Environmental and Resource Economics, 22: 157184.

Arora, S. (2001), "Voluntary Abatement and Market Value: An Event Study Approach", Discussion Paper no. 00-30, Stanford Institute for Economic Policy Research,

Blackman, A. and G.J. Bannister (1998), "Community Pressure and Clean Technology in the Informal Sector: An Economteric Analysis of the Adoption of Propane by Traditional Mexican Brickmakers", Journal of Environmental Economics and Management, 35: 1-21.

Boardman, A., Vertinsky, I. and D. Whistler (1997), "Using Information Diffusion Models to Estimate the Impacts of Regulatory Events on Publicly Traded Firms", Journal of Public Economics, 63: 283-300.

Dasgupta, S., Laplante, B. and N. Mamingi (2001), "Pollution and Capital Markets in Developing Countries", Journal of Environmental Economics and Management, 42: 310-335.

Fama, E.F. (1991), "Efficient Capital Markets II", Journal of Finance, 40: 1575-1617.

Henderson, G.V. (1990), "Problems and Solutions in Conducting Event Studies", Journal of Risk and Insurance, 57(2): 282-306.

Khanna, M., Quimio, W.R.H. and D. Bojilova (1998), "Toxics Release Information: A Policy Tool for Environmental Protection", Journal of Environmental Economics and Management, 36: 243-266.

Konar, S. and M.A. Cohen (2001), "Does the Market Value Environmental Performance?", Review of Economics and Statistics, 83(2): 281-289.

Lanoie, P., Laplante B. and M. Roy (1998), "Can Capital Markets Create Incentives for Pollution Control?", Ecological Economics, 26: 31-41.

MacKinlay, A.C. (1997), "Event Studies in Economics and Finance", Journal of Economic Literature, 35(1): 13-39. 
McWilliams, A. and D. Siegel (1997), "Event Studies in Management Research: Theoretical and Empirical Issues", Academy of Management Journal, 40(3): 626-657.

Pargal, S. and D. Wheeler (1996), "Informal Regulation of Industrial Pollution in Developing Countries: Evidence from Indonesia", Journal of Political Economy: 104: 1314-1327.

Tawil, N. (1999), "Flow Control and Rent Capture in Solid Waste Management", Journal of Environmental Economics and Management, 37(2): 183-201.

Wang, H., J. Bi, D. Wheeler, J. Wang, D. Cao, G. Lu, and Y. Wang (2002), "Environmental Performance Rating and Disclosure: China's Green Watch Program", World Bank Policy Research Working Paper 2889, September.

World Bank (1999), Greening Industry: New Roles for Communities, Markets and Governments, New York: Oxford/World Bank. 


\section{Appendix 1-A: Weights for rating of pulp and paper firms}

\begin{tabular}{|c|c|}
\hline & Weight \\
\hline $\begin{array}{l}\text { Corporate environmental policy and management systems } \\
\text { (i) corporate environmental policy (7) } \\
\text { (ii) corporate policy on procurement of raw materials, water, energy and chemicals (3) } \\
\text { (iii) corporate policy on waste management, technology adoption, and community } \\
\text { relations and communications (2) } \\
\text { (iv) status of corporate environmental management (19.5) } \\
\text { (v) transparency (2) } \\
\text { (vi) awards (1.5) }\end{array}$ & 35 \\
\hline $\begin{array}{l}\text { Plant-level environmental performance } \\
\text { (i) input management (8) } \\
\text { (ii) process management (including recycling and reuse of resources and wastes (31) } \\
\text { (iii) waste management (11) }\end{array}$ & 50 \\
\hline Product use performance & 0 \\
\hline Product disposal performance & 0 \\
\hline $\begin{array}{l}\text { Community and regulatory perception and compliance status } \\
\text { (i) compliance with pollution control board (PCB) regulations and perception of PCB } \\
\text { officials (2.5) } \\
\text { (ii) perception of local community ( } 7.5) \\
\text { (iii) perception of local NGOs and media (2.5) } \\
\text { (iv) perception CSE's green inspector (2.5) }\end{array}$ & 15 \\
\hline Total & 100 \\
\hline
\end{tabular}

Source: "Enter the Green Rating Project", Centre for Science and Environment, New Delhi 1999. 


\section{Appendix 1-B: Weights for rating of automobile firms}

\begin{tabular}{|c|c|}
\hline \multirow{2}{*}{ Environmental performance of supply chain } & Weight \\
\hline & 7.5 \\
\hline $\begin{array}{l}\text { Environmental performance of production plant } \\
\text { (i) consumption efficiency (1.5) } \\
\text { (ii) process management and process efficiency (4) } \\
\text { (iii) pollution generation and pollution prevention and control (2.5) } \\
\text { (iv) compliance status at production plant (0.5) } \\
\text { (v) perception of CSE's green inspector (3) }\end{array}$ & 11.5 \\
\hline $\begin{array}{l}\text { Environmental impact during product use } \\
\text { (i) vehicle and engine design (34.5) } \\
\text { of which } \\
\text { (a) geometric design of the engine (10.5) } \\
\text { (b) fuel supply technology of the vehicle (6) } \\
\text { (c) displacement per cylinder (3) } \\
\text { (d) compression ratio (3) }\end{array}$ & 56 \\
\hline $\begin{array}{l}\text { (ii) pollution control equipment (12) } \\
\text { (iii) emissions and noise pollution from vehicles (9.5) }\end{array}$ & \\
\hline End-of-life disposal/recycling of product & 5 \\
\hline Corporate environmental policy and management systems & 20 \\
\hline Total & 100 \\
\hline
\end{tabular}

Source: "Green Rating Project: Environmental Rating of Indian Automobile Sector," Centre for Science and Environment 2001. 
Appendix 2-A: Ratings of pulp and paper mills

\begin{tabular}{|c|c|c|c|c|c|}
\hline & Name & $\begin{array}{l}\text { Installed capacity } \\
\text { (metric tons/year) }\end{array}$ & $\begin{array}{l}\text { Weighted } \\
\text { score }\end{array}$ & Rank & $\begin{array}{l}\text { Rating } \\
\text { (no. of } \\
\text { leaves) }\end{array}$ \\
\hline 1 & JK Paper Mills & 90,000 & 42.75 & 1 & 3 \\
\hline 2 & Andhra Pradesh Paper Mills & 98,500 & 38.50 & 2 & 3 \\
\hline 3 & Sinar Mas Pulp \& Paper (India) & 115,000 & 37.40 & $\#$ & \\
\hline 4 & BILT-Ballarpur Unit & 150,000 & 33.44 & 3 & 2 \\
\hline 5 & Hindustan Newsprint & 100,000 & 33.30 & 4 & 2 \\
\hline 6 & SIV Industries & 60,000 & 31.73 & 5 & 2 \\
\hline 7 & Pudumjee Pulp \& Paper Mills & 33,000 & 31.44 & 6 & 2 \\
\hline 8 & Tamil Nadu Newsprint \& Papers & 180,000 & 31.40 & 7 & 2 \\
\hline 9 & ITC-Bhadrachalam Paperboards & 62,500 & 31.15 & 8 & 2 \\
\hline 10 & Century Pulp \& Paper & 151,920 & 31.07 & 9 & 2 \\
\hline 11 & HPCL-Nagaon Paper Mills & 100,000 & 28.70 & 10 & 2 \\
\hline 12 & Seshasayee Paper \& Boards & 60,000 & 28.20 & 11 & 2 \\
\hline 13 & West Coast Paper Mills & 119,750 & 27.67 & 12 & 2 \\
\hline 14 & BILT-Asthi Unit & 35,000 & 27.10 & 13 & 2 \\
\hline 15 & BILT-Yamunanagar Unit & 70,000 & 25.70 & 14 & 2 \\
\hline 16 & Central Pulp Mills & 45,000 & 25.35 & 15 & 2 \\
\hline 17 & Star Paper Mills & 53,000 & 24.76 & 16 & 1 \\
\hline 18 & Shree Vindhya Paper Mills & 33,000 & 24.70 & 17 & 1 \\
\hline 19 & BILT-Sewa Unit & 30,000 & 23.75 & 18 & 1 \\
\hline 20 & Orient Paper Mills & 85,000 & 22.10 & 19 & 1 \\
\hline 21 & Mysore Paper Mills & 130,000 & 21.60 & 20 & 1 \\
\hline 22 & Cachar Paper Mills & 100,000 & 21.43 & 21 & 1 \\
\hline 23 & Rama Newsprint \& Papers & 61,380 & 21.10 & 22 & 1 \\
\hline 24 & BILT-Chaudwar Unit & 20,000 & 21.06 & 23 & 1 \\
\hline 25 & Nath Pulp \& Paper Mills & 41,750 & 20.80 & 24 & 1 \\
\hline 26 & Grasim Industries (Mavoor) & 57,600 & 20.65 & 25 & 1 \\
\hline 27 & Mukerian Papers & 34,650 & 20.01 & 26 & 1 \\
\hline 28 & Amrit Papers & 26,400 & 19.01 & 27 & 1 \\
\hline
\end{tabular}

\# Sinar Mas was operational only since 1996-97 and therefore it was not included in the rankings. Source: The Green Rating Project, Centre for Science and Environment, New Delhi. 
Appendix 2-B: Ratings of automobile firms

\begin{tabular}{|l|l|l|l|l|}
\hline & Name & Weighted score & Rank & $\begin{array}{l}\text { Rating } \\
\text { (no. of leaves) }\end{array}$ \\
\hline 1 & Daewoo Motors India Ltd. & 43.54 & 1 & 3 \\
2 & Hyundai Motors India Ltd. & 41.93 & 2 & 3 \\
3 & General Motors India & 40.78 & 3 & 3 \\
4 & Mercedes-Benz India Limited & 39.63 & 4 & 3 \\
5 & Hero Honda Motors Ltd. & 39.57 & 5 & 3 \\
6 & Maruti Udyog Ltd. & 39.14 & 6 & 3 \\
7 & Honda-Siel & 38.23 & 7 & 3 \\
8 & Ford India Ltd. & 37.62 & 8 & 3 \\
9 & Fiat India & 35.67 & 9 & 3 \\
10 & Volvo India Pvt. Ltd. & 34.60 & 10 & 2 \\
11 & Bajaj Auto Ltd. & 32.84 & 11 & 2 \\
12 & Tata Engg.\& Loco.Ltd. & 32.03 & 12 & 2 \\
13 & Hindustan Motors Ltd. & 31.11 & 13 & 2 \\
14 & TVS Suzuki Ltd. & 30.86 & 14 & 2 \\
15 & LML Limited & 29.36 & 15 & 2 \\
16 & Toyota Kirloskar Motors & 28.13 & 16 & 2 \\
17 & Scooters India Ltd. & 27.84 & 17 & 2 \\
18 & Kinetic Motor Company Ltd. & 27.44 & 18 & 2 \\
19 & HM-Mitsubishi Lancer & 27.38 & 19 & 2 \\
20 & Ashok Leyland Ltd. & 26.41 & 20 & 2 \\
21 & Eicher Motors Ltd. & 25.07 & 21 & 2 \\
22 & Mahindra \& Mahindra Ltd. & 24.15 & 22 & 1 \\
23 & Royal Enfield Motors & 23.22 & 23 & 1 \\
24 & Majestic Auto Ltd. & 20.52 & 24 & 1 \\
25 & Hero Puch & 20.26 & 25 & 1 \\
26 & Kinetic Engineering Ltd. & 15.82 & 26 & 1 \\
27 & Bajaj Tempo Ltd. & 0.00 & 27 & - \\
28 & Yamaha Motors Escorts Ltd. & 0.00 & 27 & - \\
29 & Swaraj Mazda Ltd. & 0.00 & 27 & - \\
\hline
\end{tabular}

Source: The Green Rating Project, Centre for Science and Environment, New Delhi. 
Appendix 2-C: Ratings of chlor alkali firms

\begin{tabular}{|l|l|l|l|l|}
\hline & Name & Weighted & Rating (no. of \\
\hline 1 & Chemfab Alkalis Ltd. & Rank & leaves) \\
2 & Shriram Alkalis \& Chemicals Ltd & 46.6 & 1 & 3 \\
3 & Indian Rayon \& Industries Ltd. & 45.3 & 2 & 3 \\
4 & Indian Petrochemicals Corporation Ltd. & 38.8 & 3 & 3 \\
5 & Search Chem Industries Ltd. & 38.6 & 4 & 3 \\
6 & Sree Rayalseems Alkalis \& Allied Chemicals Ltd. & 36.2 & 5 & 3 \\
7 & TamilNadu Petroproducts Ltd. & 35.4 & 6 & 3 \\
8 & Gujarat Alkalis \& Chemicals Ltd. - Vadodra & 35 & 7 & 3 \\
9 & Grasim Industries Ltd. & 30.4 & 9 & 2 \\
10 & BILT Chemicals & 30.36 & 10 & 2 \\
11 & Century Rayon Ltd. & 29.6 & 11 & 2 \\
12 & Gujarat Alkalis \& Chemicals Ltd. - Dahej & 28.9 & 12 & 2 \\
13 & Shriram Chemicals \& Fertilizers Ltd. & 28.7 & 13 & 2 \\
14 & DCW Ltd. & 28.2 & 14 & 2 \\
15 & SIEL Ltd. & 27.4 & 15 & 2 \\
16 & Bihar Caustic and Chemicals Ltd. & 25.4 & 16 & 2 \\
17 & Kanoria Chemicals Ltd. & 24.8 & 17 & 1 \\
18 & Standard Industries Ltd. & 24.2 & 18 & 1 \\
19 & Hukumchand Jute \& Industries Ltd. (HJI - GMMCO) & 21.7 & 19 & 1 \\
20 & NRC Ltd. - Chemical Division & 20.3 & 20 & 1 \\
21 & Punjab Alkalis \& Chemicals Ltd. & 19.9 & 21 & 1 \\
22 & Travancore Cochin Chemicals Ltd. & 15.1 & 22 & 1 \\
23 & Andhra Sugars - Kovvur & 0.0 & 23 & - \\
24 & Andhra Sugars - Saggonda & 0.0 & 23 & - \\
25 & Chemplast Sanmar Ltd. & 0.0 & 23 & - \\
\hline
\end{tabular}

Source: The Green Rating Project, Centre for Science and Environment, New Delhi.

* Complete list of Working Papers is available at the CDE Web site: http://www.cdedse.org/worklist.pdf 